\title{
How Ready Were Malaysian Undergraduates for the Sudden Online Classes During the COVID-19 Pandemic?
}

\author{
Samsiah Abdul-Hamid ${ }^{1 *}$ and Rohani Hamzah ${ }^{1}$ \\ ${ }^{1}$ Centre for Fundamental and Continuing Education, Universiti Malaysia Terengganu \\ *Corresponding author. Email: samsiah@umt.edu.my
}

\begin{abstract}
On 18 March 2020, Malaysia was placed under a series of Movement Control Orders which resulted in delays in teaching and learning in the classrooms at all levels of education and most universities were instructed to conduct online classes by April 2020. This paper looks into the readiness of Malaysian undergraduates in switching from their usual mode of face to face learning to all online classes. Two hundred and eighty- nine respondents from six public universities participated in this study. Data were collected by sending out a survey questionnaire through google form and links in students' Whatsapp groups. The survey was a compilation of several research instruments and was designed to obtain feedbacks on students' experience of online learning during the MCO due to the Covid-19 pandemic between April to June 2020. The findings indicate that for the most part, the respondents were quite prepared and were ready in terms of knowledge of using technology in learning and skills required for learning online. In this regard, universities have in fact for sometimes been keeping abreast with emerging technology innovation of a modern society and hence successfully prepared the students well before the pandemic outbreak with blended learning strategy and the use of technology in classrooms. However, the findings also indicate that the respondents were less prepared in terms of facilities for an efficient online learning such as an up-to-date laptop, internet coverage plan and internet access.
\end{abstract}

Keywords: Covid-19, teaching and learning, online learning, students' readiness, technology in learning

\section{INTRODUCTION}

Soon after the Malaysian government's announcement of the Movement Control Order (MCO) on $16^{\text {th }}$ March 2020 to take effect on $18^{\text {th }}$ March 2020, college students around the country scrambled for bus, train and flight tickets to self-quarantine in their own hometown. Some were lucky to get tickets but many were stranded on their respective campuses. Then everything came to a halt, except for essential businesses.

COVID-19 has disrupted the traditional face to face and hands-on teaching and learning practices in almost all educational settings worldwide [1]. Physical classroom presence has to be suspended in order to abide by the MCO and ensure the health safety of lecturers, students, laboratory and administrative personnel. All involved parties in the education sector from around the world struggled to come up with a decisive plan of action to compensate for the loss of face to face class time and the need to complete the required syllabus. Fortunately, information technology has made e-learning possible, hence online learning was deemed the safest and best solution to the current educational predicament during the pandemic [1]. COVID-19 has changed the educational landscape of the $21^{\text {st }}$ century forever and forced everyone to accept it as a new norm. With the pandemic continues to rage, lecturers began teaching in front of their computer screen while students were expected to learn, focus and take tests through the internet. Yet, how ready were the students to be pushed into the far end of the educational practice spectrum without a hint of warning aside from a one-day lull before the MCO?

\section{LITERATURE REVIEW}

The introduction of CAL (Computer Assisted Learning), Web-Based Distance Learning, LMS (Learning 
Management Systems), and the latest MOOC (Massive Open Online Courses) have gradually transformed the teaching practices at higher learning institutions [2]. The adoption of blended learning in each of the courses offered at the university has taken effect for several years [3] and universities have invested considerable resources to ensure better delivery of university education in the times of Information Technology and Artificial Intelligence. The initial objective of blended learning is to incorporate online resources in a course while retaining the traditional teacher-led instructions [3]-[4]. In no time, this online instructional methodology has proven beneficial in multiple ways such as permitting easy access to course content and lecture notes, making the best use of online media and resources for optimal learning engagement, providing a secure platform for efficient submission and return of coursework, and enabling assessments to be taken simultaneously for both campus-based and distance students [5].

Yet, to go fully online requires substantial planning and investments by not only the university but also the parents of university going children and the students themselves [6]. Not only that the university needs to invest on internet-related facilities and on lecturers training in using the available online teaching platform and applications, the students ought to have been prepared with internet coverage, up-to-date computing tools and computer skills. Without proper and careful planning and preparations, the effort to conduct full online classes are doomed to fail [7], or so we thought. Unfortunately, all universities around the world had a window of only a few days to make the ultimate decision to go for fully online learning for all courses when the pandemic initially broke out.

A few researchers have examined the demographic background of online students as a factor that contributes to their readiness to study online [8]-[9]. Among the contributing demographic factors for learners to study fully online are older students compared to younger students [8], more female compared to male students [10], and those who have had prior online learning experience compared to first timers [11]. Evidently, online learners in previous studies were those who voluntarily registered for online classes or those who had taken been participating in blended learning courses. While the first were willing and seemed prepared to study online, the latter had the support of face to face teacher-led classes. Unlike the two scenarios, involuntary enrolment in online classes as per the COVID-19 situation, socio-economic background which suggests superior versus inferior computing tools as well as home location and internet coverage could have influenced the students' readiness to go fully online and compromised their academic performance.

Besides the computing tools, online learning necessitates the learners to be highly independent and ready to adopt new ways of doing things such as searching, organising, preparing, and completing materials and assignment. Three key factors that influence students' readiness for online learning are students' attributes, time management competencies and technical skills [9]. Ilgaz \& Gülbahar (2015) [12] believe that the convenience of having online learning will be hampered if these three factors are compromised.

According to Lin and Hsieh (2001) [13], learners must take responsibility for their own learning in order to succeed by having high self-discipline and the ability to learn in any given formats, either through synchronous or asynchronous technology. Hence, knowing what to expect from an online course and thus set goals to succeed, the ability to adapt to a variety of teaching methods and formats and the know how in learning new things by oneself are the key online student attributes which should be evidenced in online learners.

Successful online learning is also very much dependent on students' management of self and in particular time management. It has been reported in the literature that among the challenges of time management are being able to follow the course content, complete assignments on time [14], and participate in a synchronous class discussion [15]. Additionally, the ease of online learning is further influenced by the learners' internet self-efficacy [16]. Internet self-efficacy underscores the role of technological skills such as computer skills, researching, organising and downloading information skills [17], and installing software skills [18].

The existing studies on online learning readiness have outlined a number of determinants for successful online classes ranging from the internet facilities and teacher training invested by the university, to computing tools, internet coverage as well as students' online attributes, time management and technical skills. Yet, when COVID19 pandemic broke out, such hasty decision to go fully online may have left some students struggling to keep up.

This paper examines student readiness for online learning during the early days of COVID-19 pandemic in order to provide insights for future online education before the world fully recovers from the pandemic.

The Research Questions are:

1. What demographic factors contributes to students' readiness for online learning during the COVID 19 outbreak?

2. What online attributes and competencies did the students possess at the start of their full online learning during the COVID 19 outbreak?

\section{METHODOLOGY}

\subsection{Participants}

The study was conducted on undergraduates of different degree and diploma programmes in the public universities in Malaysia who were directly affected by the sudden shutdown of all university campuses due to the rapid spread of COVID-19 in March 2020 and were required to continue their classes online. The researcher targeted 500 respondent feedbacks but since the questionnaire was distributed online through google form, a 50\%-60\% response rate is considered good. 


\subsection{Instrument}

The instrument used for this study was named Online Learning During the Pandemic COVID-19 which was an adaptation from a number of instruments on online learning before COVID-19 [5];[19]-[20] and during the COVID-19 pandemic [6];[9];[21].

The instrument contains five parts which are on respondents' agreement to participate voluntarily, demographic information, readiness to learn online, perception of attending online language classes during the pandemic, and a comparison of attending online classess to face to face classes. The first part requires respondents to state their agreement or disagreement to participate in the study by choosing one of the options given. Part 2 of the instrument contains 13 items that assess the respondents' background information such as age, gender, university, year and programme of study, IT skills, internet coverage plan and strength, and family financial status. Part 3 of the instrument assesses respondents' online learning readiness prior to the COVID-19 pandemic. Three key components are online learning attributes, time management competency and technical skills. While parts 4 and 5 delve into their perception of the learning online versus learning face to face before and during the COVID-19 pandemic.

The reliability index for this instrment with 37 items was at Cronbach's Alpha .935, which is considered high and reliable.

\subsection{Procedure}

This instrument was prepared in the Malay language which is the first language of the majority of the respondents and a national langauge for all Malaysians. The questions were transferred onto google form and a link was shared in students' whatsapp groups by lecturers in a number of universities. The respondents were given the link and requested to respond after their formal online classes had ended. This is to ensure that there was no pressure for the respondents to be truthful in answering the questionnaire as it would not affect their grades. Data collection took about one month and it took an average of 15 minutes for a respondent to complete answering the questionnaire.

\section{RESULTS}

\subsection{Preliminary Findings}

Two hundred and eighty-nine Malaysian undergraduates responded to the questionnaire. From this number, 5 respondents chose the option of disagreement to participate, hence their responses were deleted from the data base and were not analysed in answering the research questions.
Table 1 Respondents' voluntary agreement to participate

\begin{tabular}{lll}
\hline Option & Freq & Percent \\
\hline I disagree & 5 & 1.7 \\
\hline $\begin{array}{l}\text { I agree as long as my data remains } \\
\text { anonymous }\end{array}$ & 59 & 20.4 \\
$\begin{array}{l}\text { I agree as it will contribute to the } \\
\begin{array}{l}\text { improvement of future online classes } \\
\text { N }\end{array}\end{array}$ & 225 & 77.9 \\
& & 100 \\
\hline
\end{tabular}

After the 5 responses were deleted, the study was left with 284 responses for further analysis. The following table displays the background of the 284 respondents who agreed to participate in the study.

Table 2 displays the descriptive background of the 284 respondents. Eighty percent of the respondents were 21 to 23 years old, and $70.4 \%$ were female students. Most of the respondents came from Universiti Malaysia Terengganu $(77 \%)$ while the rest came from four other public universities in Malaysia. The respondents consist of students enrolled in Diploma and bachelor's degree programmes in their first second and final year of study. $57.4 \%$ of the respondents were from social science and business management and $34.2 \%$ from Science and $8.5 \%$ from technology. Three different household income groups in Malaysia are known as T20, M40 and B40 which refer to the high, middle and low income categories [22]. Of the 284 respondents, 218 of $\mathrm{t}$ hem $(76.8 \%)$ came from the low income group or the bottom $40 \%$ (B40) with total family income betweenRM4849 to RM2500 and below a month. $19.4 \%$ or 55 respondents came from middle income group (M40) with total family income between RM4850 to RM10,959 and only $3.9 \%$ or 11 people came from top income group (T20) with family total income RM11,000 and above.

Table 2 Respondents' descriptive statistics

\begin{tabular}{|c|c|c|c|}
\hline \multicolumn{2}{|r|}{ Variable } & Freq & Percent \\
\hline \multirow[t]{3}{*}{ Age } & $19-20$ years old & 40 & 14 \\
\hline & $21-23$ years old & 227 & 80 \\
\hline & 24-26 years old & 17 & 9.7 \\
\hline \multirow[t]{2}{*}{ Gender } & Male & 84 & 29.6 \\
\hline & Female & 200 & 70.4 \\
\hline \multicolumn{2}{|c|}{ Universiti Malaysia Terengganu } & 219 & 77.1 \\
\hline \multicolumn{2}{|c|}{ Universiti Sultan Zainal Abidin } & 21 & 7.4 \\
\hline \multicolumn{2}{|c|}{ Universiti Malaysia Sarawak } & 19 & 6.7 \\
\hline \multicolumn{2}{|c|}{ University Malaya } & 22 & 7.5 \\
\hline \multicolumn{2}{|c|}{ Universiti Teknologi Malaysia } & 3 & 1.1 \\
\hline \multirow{4}{*}{$\begin{array}{l}\text { Year of } \\
\text { study }\end{array}$} & & Dip Deg & \\
\hline & First Year & 82 & 35.2 \\
\hline & Second Year & 77 & 28.5 \\
\hline & Final Year & 104 & 36.3 \\
\hline \multirow{3}{*}{$\begin{array}{l}\text { Field of } \\
\text { study }\end{array}$} & Science & 97 & 34.2 \\
\hline & Technology & 24 & 8.5 \\
\hline & Social Science \& Mgt & 163 & 57.4 \\
\hline \multirow{3}{*}{$\begin{array}{l}\text { Income } \\
\text { Group }\end{array}$} & B40 & 218 & 76.7 \\
\hline & M40 & 55 & 19.4 \\
\hline & $\mathrm{T} 20$ & 11 & 3.9 \\
\hline
\end{tabular}




\subsection{Research Question 1}

To answer the first research question on the demographic factors that may contribute to students' readiness for online learning during the COVID 19 outbreak, socio economic background, location of hometown and internet coverage plan were analysed.

Table 3 Respondents' family income per month

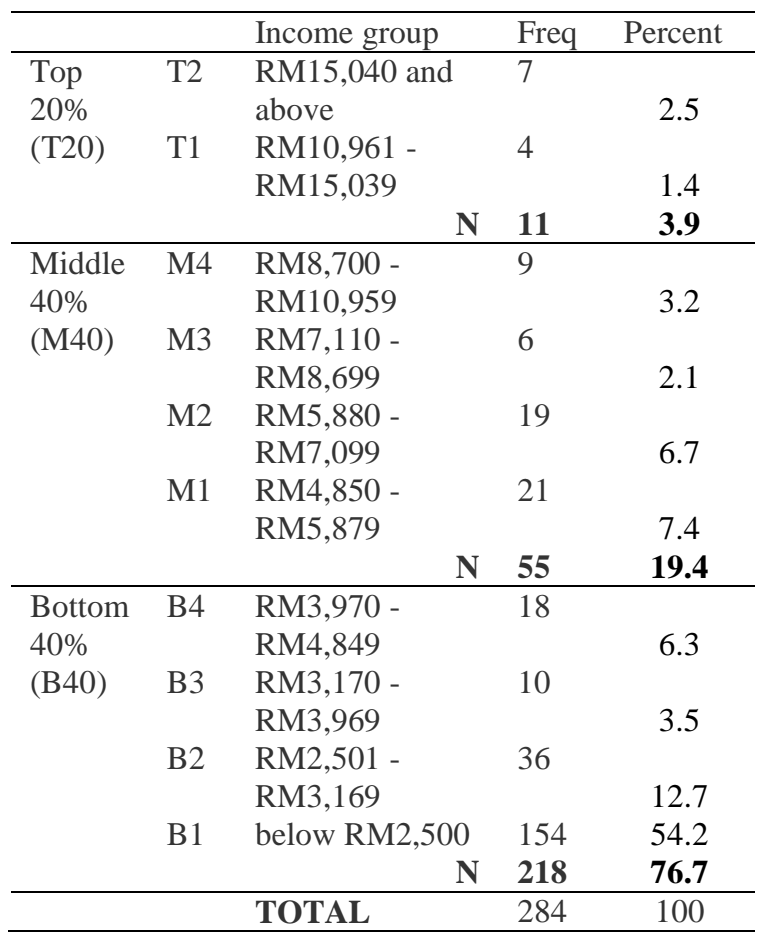

The analysis of the respondents' financial status in a month as displayed in Table 3 revealed that more than two third of the respondents which was $218(76.7 \%)$ came from a B40 family. In fact, half or $54.2 \%$ of them came from the lowest rung of B40, a family that earned below RM2500 a month. This financial situation could certainly impact the learners' readiness for online learning as it involves a huge amount of financial investment on the parents to ensure online learning ease for the college going children during the COVID-19 pandemic. Tables 4 and 5 illustrate data on internet coverage at the homes of the online learners during the MCO.

Table 4 Respondents' internet access plan at home

\begin{tabular}{|c|c|c|c|}
\hline Internet access plan & & Freq & Percent \\
\hline Home wifi & & 102 & 35.9 \\
\hline Mobile data & & 176 & 63.0 \\
\hline Hot spot wifi & & 6 & 2.1 \\
\hline & $\mathrm{N}$ & 284 & 100 \\
\hline
\end{tabular}

Table 5 Respondents' internet access speed at home vs actual internet accessibility during class

\begin{tabular}{lll}
\hline $\begin{array}{l}\text { Presumed internet } \\
\text { access speed }\end{array}$ & Freq & Percent \\
\hline Very fast & 14 & 4.9 \\
$\begin{array}{l}\text { Fast } \\
\text { Moderate }\end{array}$ & 81 & 28.5 \\
Slow & 164 & 57.7 \\
\hline & 25 & 8.8 \\
\hline & $\mathbf{2 8 4}$ & $\mathbf{1 0 0}$ \\
$\begin{array}{l}\text { Actual internet line } \\
\text { during class }\end{array}$ & Freq & Percent \\
\hline $\begin{array}{l}\text { Internet line OK } \\
\begin{array}{l}\text { Internet line slow/ } \\
\text { unstable }\end{array}\end{array}$ & 109 & 38.4 \\
\hline \multicolumn{2}{c}{175} & 61.6 \\
\hline
\end{tabular}

As revealed in Table 4, 102 or $35.9 \%$ of the respondents had home wifi which was paid by the parents for the ease use of internet for online learning or entertainment. It could be assumed that these were the respondents who enjoyed a very fast $(4.9 \%)$ and fast $(28.5 \%)$ internet access speed at home as indicated by the data in Table 5 . Hence, the responses of $38.4 \%$ that the internet line during classes in the time of MCO due the COVID-19 pandemic was $\mathrm{OK}$.

In contrast, $65 \%$ of the respondents were using mobile data or family's hot spot from mobile data to access the internet. While the use of mobile data can ensure accessibility, it could also pose problems as $57.7 \%$ and $8.8 \%$ reported that their internet line was at moderate and slow speed. Even more disappointing for online learning, when the line was slow and unstable when classes were in progress as reported by $61.6 \%$ of the respondents.

Table 6 below displays the distribution of home location of the respondents in this study. As many as $42.3 \%$ and $27.8 \%$ lived in urban and semi urban areas where it was assumed to have better internet coverage and reception and only $29.2 \%$ lived in rural and semi-rural areas. Yet, the data in Table 5 revealed that only $33.4 \%$ had very fast and and fast internet line. Hence, assuming that geographical locations could predict better internet coverage is far from the truth.

Table 6 Respondents' hometown during the COVID-19 MCO

\begin{tabular}{lcc}
\hline Hometown location & Freq & Percent \\
\hline Urban & 120 & 42.3 \\
Semi Urban & 79 & 27.8 \\
Semi Rural & 41 & 14.4 \\
Rural & 42 & 14.8 \\
\hline
\end{tabular}

The data were further analysed to determine what factor or factors that caused the learners to have weaker internet line, their hometown location or their internet plan a 
Table 7 Crosstabulation of weak internet coverage during online classes at the time of MCO, COVID-19

\begin{tabular}{|c|c|c|c|c|}
\hline $\begin{array}{l}\text { Internet } \\
\text { Package }\end{array}$ & Location & $\begin{array}{l}\text { Family income } \\
\text { per month }\end{array}$ & Freq & Percent \\
\hline Pre-Paid & Mixed of Urban, Semi Urban, Semi Rural \& & B40: & 96 & \\
\hline \multirow{10}{*}{ Mobile Data } & Rural areas & $\mathrm{B} 2$ & 12 & \\
\hline & (eg: Kuala Lumpur, Kodiang, Bitangor, & B3 & 6 & \\
\hline & Mentakab, Kajang, Teluk Intan) & B4 & 3 & \\
\hline & & $\mathrm{N}$ & 118 & 41.5 \\
\hline & Kuala Lumpur, Bangi, Alor Setar, Kuala & M40: M1 & 3 & \\
\hline & Terengganu, Semenyih, Jerteh, Baling, & M2 & 4 & \\
\hline & Tumpat, Benut & M3 & 3 & \\
\hline & & M4 & 2 & \\
\hline & & $\mathrm{N}$ & 12 & 4.2 \\
\hline & Jengka, Bahau, Seremban & T20: $\quad$ T1 & 3 & 1.1 \\
\hline \multirow[t]{10}{*}{ Home Wifi } & Mixed of Urban, Semi Urban, Semi Rural \& & B40: & 17 & \\
\hline & Rural areas & B2 & 3 & \\
\hline & (eg: Kuching, Kuala Lumpur, Miri, Tapah) & B3 & 1 & \\
\hline & & B4 & 8 & \\
\hline & & $\mathrm{N}$ & 29 & 10.2 \\
\hline & Kuala Nerang, Ipoh, Sarikei, Kepala Batas & M40: & 1 & \\
\hline & & M2 & 2 & \\
\hline & & M4 & 1 & \\
\hline & & $\mathrm{N}$ & 4 & 1.4 \\
\hline & Kuching, Seremban & T20: & 2 & 0.7 \\
\hline
\end{tabular}

Table 7 displays data on weak internet access based on three variables which are the internet plan, hometown location and family's monthly income. The data reveals that $41.5 \%$ or 118 of the total respondents who were mainly from the B40 income category suffers the most during the full online learning due to the weak internet access. Out of the $41.5 \%$ or 118 respondents, $81.4 \%$ or 96 of them were those earning below RM2500 a month. The number of respondents suffering from weak internet access dwindled based on family income groups. The data also reveals that weak internet access cannot be assumed from the hometown location. This is because, the data indicates that weak internet access occur in urban as well as rural areas.

When Tables 4 and 7 together are analysed together, the data reveals that the use of pre-paid mobile data was the most popular internet package among the respondents in the B40 groups. Out of 179 respondents that used this plan, 133 of them had problems with internet accessibility. In contrast, out of 102 respondents who used home wifi provided by the family, only 35 had the same problem.

\subsection{Research Question 2}

The following analyses will try to answer research question 2 on the attributes and competencies that the respondents possessed at the start of their full online learning during the COVID 19 outbreak.

Table 8 displays four statements on online student attributes which are designed to access respondents' selfcontrol and their ability to study independently. The attributes are about their ability to set goals and complete assignments, self-discipline to complete the course, and the ability to learn about and learn from new technology. The composite score for these attributes is 3.68.

Table 8 Online student attributes possessed by respondents at the start of online classes due to MCO, COVID-19

\begin{tabular}{llcc}
\hline Q & Competency & Mean & SD \\
\hline & Online student attributes & & \\
5 & I can learn new online apps on my own. & 3.73 & 0.99 \\
6 & I know the deadlines of all assignments and set goals to achieve them. & 4.02 & 0.93 \\
7 & I am a disciplined person when it comes to my studies. & 3.64 & 0.87 \\
9 & I can focus in learning from a variety of formats such as videos, online conferencing, & & \\
& written instructions. & 3.32 & 0.99 \\
\end{tabular}


All the means were in the range of 3.00 point except for the statement knowing deadlines and setting goals to achieve that which was 4.01 . This suggested that on average, respondents reported they had a moderate online student attributes given that they had some prior experience of online learning, albeit blended learning, in the semester before the COVID-19 pandemic. The item for question 9 which was on the ability to learn from a variety of formats may have been a little tough for most respondents especially without the integration of face to face instruction and especially so for first year students.

Table 9 displays two key competencies in learners' time management and technical skills. Time management is a challenging skill for online learning as it requires a high self-discipline to attend both synchronous and more so for asynchronous lessons. Both demand effort since they are learning in the comfort of their own home, unlike face to face classes where the schedule has been set.

Technical skills involve the ability of online learners to use computer, edit, upload, seek information, use current web applications and learn through web-based tasks. Such competency eases online learning and puts less pressure on online learners to catch up on learning to navigate the internet and new web-based tools.

Table 9 Time management and technical competencies possessed by respondents at the start of online classes due to MCO, COVID-19

\begin{tabular}{llcc}
\hline Q & Competency & Mean & SD \\
\hline & Time Management & & \\
8 & I put aside a few hours a day for revision and assignments. & 3.44 & 0.92 \\
10 & I complete course assignments on time. & 3.88 & 0.96 \\
11 & I am punctual in attending my face to face classes. & 3.87 & 0.92 \\
& & $\mathbf{3 . 7 3}$ & \\
& & \\
& Technical Competence & 4.04 & 0.91 \\
1 & I can create and edit documents, manage files and folders in the computer. & \\
2 & I know how to navigate through the course (for quizzes, notes, materials) using the university \\
& Learning Management System such as Moodle, Canvas, Blackboard, google Classroom and etc. & 3.73 & 0.93 \\
3 & I know how to upload my assignments online to the university LMS & 4.31 & 0.82 \\
4 & I have participated in discussions through video conferencing such as through google meet, & 3.75 & 1.04 \\
& Webex and Zoom. & $\mathbf{3 . 9 6}$ & \\
\hline
\end{tabular}

The means for all of the items for time management competence did not go to 4.00 with the composite mean of 3.73. Time management is one skill which is not a strong fort for local university students hence the result. This skill may be one of a few obstacles faced by online learners which requires a lot of effort not only from the learners themselves but also from the instructors in training learners to be time observant if they wish to be regular and successful online learners.

The respondents rated technological competency higher than those of time management with two means reaching above 4.00 and a composite mean of 3.96. The two skills that reached over 4.00 were the fundamental computing skills such as editing, creating files and folders $(M=4.01)$ and using LMS to upload assignments $(\mathrm{M}=4.32)$. Even though the means for navigating the university LMS and using Google Classroom (Mean=3.73) and participating discussions through video conferencing $(\mathrm{M}=3.77)$ were both below 4.00, they were still high 3 pointers which suggest that these learners have had the experience at the start of the pandemic to be able to use the skill during a full online learning during the MCO.

\section{DISCUSSIONS}

This section will discuss the findings on undergraduates' readiness for the sudden online classes during the
COVID-19 pandemic based on four constructs of online learning readiness which are demographic factors, online student attributes, time management and technical competencies.

\subsection{The contribution of family socio economic background on online learning readiness}

The findings of this study revealed that $70.1 \%$ of the respondents lived in urban and semi urban areas while only $29.2 \%$ lived in rural and semi-rural areas. In comparison to the study by Dinh \& Nguyen (2020) [23] who had only $39.5 \%$ of respondents living in urban areas and a whopping $60.75 \%$ in rural areas, the respondents in the current study could have been assumed to have less difficulty in accessing their online classes. Yet, there seems to be another compound variable besides geographical locations. The data indicates that $63 \%$ or 176 of the respondents used pre-paid mobile data for their online classes and of these, $41.5 \%$ or 118 reported that their internet line was weak; and they were from the B40 income group. Alternatively, $35.9 \%$ or 102 respondents used home wifi and only $12.3 \%$ of this package users complained of weak internet line. The data may have suggested two important assumptions here. First, those from higher income groups opted for high end internet package plan, hence more expensive for higher internet 
speed and better coverage. On the other hand, those from lower income groups opted for less expensive pre-paid mobile data which provided less efficient service. Another assumption is that home wifi may be a better choice for a better internet package plan if online learning were to persist in the succeeding semesters. While Dian Hidayati et al (2020) [24] data too found that limited internet coverage in certain geographical locations to contribute the most to online learning discomfort experienced by the respondents in Indonesia, this study found that in some cases remote geographical locations could be accessed by more expensive high-speed internet coverage plan. Hence, the main hurdle remains the socio-economic income of the family.

Vollbrecht, Stransky and Lackey-Cornelison (2020) [25] highlight the fact that current virtual classes use applications that require high-speed internet which many students may not have or that the students' internet speed may not be compatible to that of the instructors. Students may also be competing for the internet line with other members of the family. Hence to lessen the discomfort of students with inferior internet connection, intermittent asynchronous lessons should be opted so that students can access the lessons when their internet access is available.

\subsection{Online student attributes}

Most respondents were moderately ready to study independently with the composite mean for this section is at 3.68. Since the first-year students had been through 5 years of teacher-led secondary education, they were still somewhat dependent on the lecturers to guide and set goals. In addition, learning through videos, video conferencing and written instructions are new norms which they have to learn to get used to. On the other hand, second and final year respondents may have acquired some independent and self-control due to their learning experience at higher learning institutions as well as the blended learning experience which was made compulsory by each university before the COVID-19 pandemic. Despite the mean composite of 3.68 , it is believed that the respondents would improve their sense of discipline, selfcontrol and independent if the full online learning were to persist.

\subsection{Time management and technical competency readiness}

Time management competency were rated moderate with a mean composite of 3.78. This competency tests the online learners' sense of responsibility towards their online classes and their overall study and performance. With the temptation of home comfort and entertainment, the difficulty to access the internet when the line is weak, and the lack of face to face watchful eyes of lecturers and peers, the learners face a great challenge to manage their time efficiently in order to succeed in online courses. This finding is consistent to the study by Rodríguez Núñez \& Leeuwner (2020) [26] that found students did struggle to schedule their learning and study time especially courses that opted for asynchronous teaching mode.

Being digital natives, the young learners were found to be skilful enough to use computer tools and software, webbased apps and new online web applications to guarantee their participations in the online learning courses. A mean composite of 3.96 suggests that these learners had upper intermediate technical competency that was sufficient enough at the start of the semester to follow the flow of all online classes.

\section{CONCLUSION}

There are several implications from the findings of the study. The findings inform the authority concerned especially to the Malaysian government that a special subsidy for the installation of efficient home wifi package is needed to ensure that students from low income family especially the B40 group do not suffer if full online learning were to continue in the succeeding semesters. The findings also inform service providers to upgrade their internet coverage and service for pre-paid data plan so that the money invested by the students was not spent in vain. The results of this study also have implications on the designs and running of online courses. As students, in particular those from the B40 group, often face internet inaccessibility due to home location and internet coverage plan, instructors should plan for more asynchronous lessons which students can access when the internet is good and less on synchronous lessons which require students to be ready not only in virtual presence but also in the amount of money invested for pre-paid mobile data.

\section{REFERENCES}

[1] UNESCO. COVID-19 educational disruption and response. (2020, March 13). Retrieved from https://en.unesco.org/covid19/educationresponse

[2] J. S. Chen Hsieh, W. C. V. Wu and M. W. Marek, Using the flipped classroom to enhance EFL learning. Computer Assisted Language Learning, 30 (12) (2017) 1-21. doi:10.1080/09588221.2015.1111910

[3] C. C. Wai and E. L. K. Seng, Measuring the effectiveness of blended learning environment: A case study in Malaysia. Education and Information Technologies, 20(3) (2015) 429-443. DOI $10.1007 / \mathrm{s} 10639-013-9293-5$

[4] M. A. Stapa and N. Muhammad, The use of addie model for designing blended learning application at vocational colleges in Malaysia. AsiaPacific Journal of Information Technology and Multimedia, 8(1) (2019) 49-62.

[5] N. Wang, J. Chen, M. Tai and J. Zhang, Blended learning for Chinese university EFL learners: learning environment and learner perceptions. Computer 
Assisted Language Learning, (2019) 1-27. DOI: 10.1080/09588221.2019.1607881

[6] J. Demuyakor, Coronavirus (COVID-19) and online learning in higher institutions of education: A survey of the perceptions of Ghanaian international students in China. Online Journal of Communication and Media Technologies, 10(3) (2020), e202018. DOI: https://doi.org/10.29333/ojcmt/8286

[7] F. Yang and F. W. Li, Study on student performance estimation, student progress analysis, and student potential prediction based on data mining. Computers \& Education, 123 (2018) 97108.https://doi.org/10.1016/j.compedu.2018.04.006

[8] G. M. Johnson, On-campus and fully-online university students: Comparing demographics, digital technology use and learning characteristics. Journal of University Teaching \& Learning Practice, 12(1) (2015) $1-15$.

[9] F. Martin, B. Stamper and C. Flowers, Examining Student Perception of Readiness for Online Learning: Importance and Confidence. Online Learning, 24(2) (2020) 38-58. doi.org/10.24059/olj.v24i2.2053

[10] F. C. Quinn, Learning in first-year biology: approaches of distance and on-campus students. Research in Science Education, 41(1) (2011) 99-121.

[11] H. Cigdam and O. G. Yildirim, Effects of students' characteristics on online learning readiness: A vocational college example. Turkish Online Journal of Distance Education, 15(3) (2014) 80-93.

[12] H. Ilgaz and Y. Gülbahar, A snapshot of online learners: e-Readiness, e-Satisfaction and expectations. International Review of Research in Open and Distributed Learning, 16(2) (2015) 171-187. doi:10.19173/irrodl.v16i2.2117

[13] B. Lin and C. T. Hsieh, Web-based teaching and learner control: A research review. Computers \& Education, 37(3-4) (2001) 377-386.

[14] Discenza, R., Howard, C. and Schenk, K. D. (Eds.). The Design and Management of Effective Distance Learning Programs. Hershey, Pa.: IGI Global. (2002).

[15] D. R. Garrison, M. Cleveland-Innes and T. Fung, Student role adjustment in online communities of inquiry: Model and instrument validation. Journal of asynchronous learning networks, 8(2) (2004) 61-74.

[16] M. J. Tsai and C. C. Tsai, Information searching strategies in web-based science learning: The role of
Internet self-efficacy. Innovations in education and Teaching International, 40(1) (2003) 43-50.

[17] J. Shi, Z. Chen and M. Tian, Internet self-efficacy, the need for cognition, and sensation seeking as predictors of problematic use of the Internet. Cyberpsychology, Behavior, and Social Networking, 14(4) (2011) 231-234.

[18] D. Boyd, The characteristics of successful online students. New Horizons in Adult Education and Human Resource Development, 18(2) (2004) 31-39.

[19] M. H. Abdous, Influence of satisfaction and preparedness on online students' feelings of anxiety. The Internet and Higher Education, 41 (2019) $34-44$.

[20] T. Muir, N. Milthorpe, C. Stone, J. Dyment, E. Freeman and B. Hopwood, Chronicling engagement: students' experience of online learning over time. Distance Education, 40(2) (2019) 262-277. DOI:

[21] M. Bączek, M. Zagańczyk-Bączek, M. Szpringer, A. Jaroszyński and B. Wożakowska-Kapłon, Students' perception of online learning during the COVID-19 pandemic: a survey study of Polish medical students. 2020. doi.org/10.21203/rs.3.rs-41178/v1

[22] N. S. Mahdzan, R. Zainudin, M. E. Abd. Sukor, F. Zainir \& W. M. Wan Ahmad, Determinants of Subjective Financial Well-Being Across Three Different Household Income Groups in Malaysia. Social Indicators Research, 146, (2019) 699-726. DOI: 10.1007/s11205-019-02138-4.

[23] L. P. Dinh and T. T. Nguyen, Pandemic, social distancing, and social work education: Students' satisfaction with online education in Vietnam. Social Work Education, 39(8) (2020) 1074-1083. DOI: $10.1080 / 02615479.2020 .1823365$

[24] D. Hidayati and W. A. Saputra, Implementation of Online Learning during the Covid-19 Epidemic in Indonesia: Assessment of Higher Education Students' Use and Implementation of Online Learning Technology. Universal Journal of Educational Research, 8(8) (2020) 4514-4519.

[25] P. J. Vollbrecht, K. A. Porter-Stransky and W. L. Lackey-Cornelison, Lessons learned while creating an effective emergency remote learning environment for students during the COVID-19 pandemic. Advances in physiology education, 44(4) (2020) 722-725.

[26] J. Rodríguez Núñez and J. Leeuwner, Changing Courses in Midstream: COVID-19 and the Transition to Online Delivery in Two Undergraduate Chemistry Courses. Journal of Chemical Education, 97(9) (2020) 2819-2824. 